\title{
Effect of GA3 and some plant extracts spraying on fruiting of Early Sweet Seedless grapevines
}

\author{
El-Salhy, A.M.*, M.F. Ebtsam, A.A. Eman, and M. D. Mona
}

\begin{abstract}
This investigation was conducted during the two successive seasons i.e. 2018 and 2019 on Early Sweet Seedless grapevines grown in Eiat vineyard, El-Odesate district, Luxor Governorate, Egypt. Five treatments of GA3 urea plus active dry yeast, roselle, lemongrass spraying and unsprayed one (control) at various stage of cluster and berry development were evaluated. The experimental vines were arranged in a complete randomized design with three replications. GA3, roselle and lemongrass were applied thrice, where urea twice followed active dry yeast once. From the results, it could be concluded that spraying either GA3, roselle or lemongrass at pre-bloom, full bloom and pea stage. In addition, spraying $1.5 \%$ urea at pre-bloom and full-bloom followed $0.4 \%$ yeast at pea stage gave heavy and less compact clusters and hastens the ripening with fairly good Early Sweet Seedless berries quality. In addition, it could be used urea plus yeast as well as roselle or lemongrass instead of GA3 in grape production to overcome the adverse GA3 effects.
\end{abstract}

Key words Growth regulators, GA3, urea, yeast, roselle, lemongrass and grapevines..

\section{INTRODUCTION}

Grapes are one of the most important deciduous fruit crops in the world and Egypt for local consumption and export, for nice taste, high nutritional values and excellent flavor. In Egypt, the cultivated area was 199212 feddan that produced about 1691194 tons of fruit (M.A.L.R., 2016).

The improving early grapes are very important either local or external markets. Berry thinning has been used to obtain good clusters with highest berry weight and fastest ripening.

\footnotetext{
*Corresponding author: A.M. El-Sally

Email: horasbaghdady@yahoo.com

Submitted: December 1, 2019;

Accepted: December 14, 2019;

Published: December 18, 2019.
}

Bunch thinning is done as a regular cultural practice or chemicals spray at pre-bloom, peak bloom and fruit set stages. This practice is done to reduce cluster compactness and to improve the berry quality.

The thinning depended on the cultivar and temperature as well as sunshine and nutrient supply (Poni, 2003; Ahmed et al., 2004 and El-Halaby et al., 2015).

Plant growth substance plays a major role in plant growth and development. GA3 still used to increase cluster length, thinning berries as well as berry size in seedless grape cultivars (Colapietra et al., 1995; Williams and Ayars, 2005; El-Halaby et al., 2015 and Radwan et al., 2019). GA3 a high concentration had adverse effects, i.e. delayed berry ripening and reduce full coloration (Dokoozlian and Peacock, 2001; El-Salhy et al., 2009 and El-Halaby et al., 2015).

So, the use of natural products in horticultural practices instead of other 
synthetic chemical products is becoming a main target for many fruit crop producers, where the world market has been growing rapidly for organic fruit production (Dimitri and Oberholtzer, 2006; El-Salhy et al., 2009; Abd-Allah et al., 2013 and El-Halaby et al., 2015).

Recently urea spraying at full bloom has been used to reduce the berry set and consequently to induce berry thinning and improve the cluster attributes (Ahmed et al., 2004; El-Salhy et al., 2009; Fawzi et al., 2014; El-Halaby et al., 2015 and Radwan et al., 2019). Also, using the active dry yeast was enhanced fruit ripening and improve berry quality, where yeast contains important nutrients, some common amino acids and some natural growth regulators (Idso et al., 1995; El-Salhy et al., 2011; Fawzi et al., 2014 and El-Halaby et al., 2015).

Plant extracts as a natural products were used many ways. The natural products were used to improve growth, nutritional status, production and as pesticides for public health and environmental safety. The plant extracts had higher content of phenolic and other chemical constituent that seem to have synergistics effects on growth and fruiting of fruit trees (Paik and Chung, 1997 and Srivastava and Lal, 1997).

Roselle (Hibiscus sabdariffa) extract contents higher amount of anthocyanin, organic acid, ascorbic acid, calcium oxalate and herbicide hydrochloride (Raffauf, 1970). Also, lemongrass (Cymbopogan citrates L.) is one of the most important essential oil because of its high citral content. It contents terpenes, alcohols, ketones, aldehyde, esters and flavonids (Shab et al., 2011). The own higher content of plant extracts from anti-oxidants especially phenolic compounds, nutrients and plant pigments which in turn stimulating the growth and fruiting of fruit trees (Srimal, 1997; Pons, 2003 and El-Salhy et al., 2017).
Previous studies emphasized the beneficial effects of using plant extracts on grapevines fruiting (Vargas et al., 2008; Abdel-Aal and Aly, 2013; Gadel-Kareem and AbdelRahman, 2013; Abd-Allah et al., 2013; Uwalkiem, 2014; Gouda-Fatma El-Zahraa, 2016; El-Salhy et al., 2017 and Radwan et al., 2019).

So, this study, aimed to study the effect of urea, yeast and plant extracts instead of the synthetic chemical products like GA3 on fruiting of Early Sweet Seedless grapevines.

\section{Materials and Methods}

The present work was conducted through two successive seasons of 2018 and 2019 on 30 uniform vigour seven years-old Early Sweet Seedless grapevines. The vines were grown in Eiat vineyard for table grapes production, El-Odesate district, Luxor Governorate, Egypt. They had grown in sandy soil at 2x3 meters apart under drip irrigation system. All vines received the standard agricultural practices that are used in the vineyard including spraying dormex, soil fertilization, irrigation and pest control. The Spanish Barron system was used as a trellising system. The vines were cane pruned (72 eyes/vine were left, 8 canes x 8 buds/cane plus 4 renewal spurs with 2 buds). The pruning was done during the second week of January each season. Crop load at all vines was adjusted to 25 clusters/vine after berry set. The chosen vines were divided into five different treatments including the control. The experimental vines were arranged in a complete randomized block design with three replications per treatment two vines each. Thus, the treatments were as follow:

Control (sprayed with water only).

GA3 seven times spraying, once at $3.5 \mathrm{ppm}$ for elongation (cluster length about (10-12 $\mathrm{cm}$ ), followed by thrice GA3 at $4.5 \mathrm{ppm}$ for thinning $(80,100$ and $120 \%$ of flowers caps 
dropped, during the successive three days, respectively) and other thrice at $5 \mathrm{ppm}$ when berry diameter reached about 5-6 $\mathrm{mm}$ (pea stage) for sizing.

Urea twice sprays at $1.5 \%$ once for elongation, followed by other for thinning and then $0.4 \%$ yeast spraying at pea stage for sizing.

Roselle at $0.2 \%$ thrice time spraying, once for elongation, followed by once for berry thinning and once for sizing.

Lemongrass oil at $0.5 \%$ three time spraying for elongation, berry thinning and berry sizing.

GA3 (Gibberellic acid), and low biuret urea (46\%), roselle extract and lemongrass were prepared before spraying by dissolved the define amount in water based. Active dry yeast was prepared by dissolved the define amount in warm water $\left(38^{\circ} \mathrm{C}\right)$ followed by addition of $0.3 \%$ Egyptian treacle (as source of sugar) and left for two hours for activating before spraying. All chemicals were sprayed at same date by using a hand sprayer to the run off.

The percentage of berry set was estimated by caging two clusters per vine in perforated white cheese bags after the first spraying. Such bags were removed for chemical spraying at blooming; the percentage of berry set was calculated as follow:

At harvest time (when TSS of berry juice in the check treatment reached $15-16 \%$ brix), the clusters were harvested, weighed and yield/vine (kg) was recorded. Two clusters were taken at random from yield of each vine and the following characteristics were determined.

Cluster weight $(\mathrm{g})$, cluster length $(\mathrm{cm})$ and number of berries per each cluster, then cluster compactness coefficient according to Winkler et al. (1974), as well as shot berries percentage were recorded.
In addition berry quality in terms of berry weight, TSS, total titratable acidity and reducing sugars \% according to A.O.A.C. (1985).

All obtained data were tabulated and statistically analyzed according to Gomez and Gomez (1984) and Snedecor and Cochran (1990) using the L.S.D. test for distinguishing the significance differences between various treatment means.

\section{Results:}

\subsection{Berry set percentage and yield:}

Data presented in Table (1) shows the effect of spraying with GA3, low biuret urea, active dry yeast, roselle and lemongrass on berry set percentage, shot berries percentage, yield/vine and cluster weight of Early Sweet Seedless grapes in 2018 and 2019 seasons. It is obvious from the obtained data that the results took similar trend during the two studied seasons. Spraying of GA3 or urea as well as roselle or lemongrass at full bloom decreased the berry set and shot berries percentages compared to untreated ones. The lowest values of berry set percentage was recorded due to spray GA3, whereas, shot berries percentage was recorded due to spray lemongrass as compared to unsprayed ones. The decrement percentage of berry set and shot berries percentage due to spray of GA3, urea, roselle or lemongrass compared to unsprayed one were attained 28.46, 25.72, $27.72 \& 27.40 \%$ and77.26, 78.35, $81.46 \&$ 83.18 as an av. of the two studied seasons, respectively.

Also all treatments significantly increased the cluster weight and yield/vine compared to unsprayed ones (control).The increment of the cluster weight and yield/vine due to spray either GA3, urea plus yeast, roselle or lemongrass over unsprayed ones (control) attained $(8.70,9.72,12.29 \& 13.89 \%)$ and 
$(10.65,12.41,12.41 \& 14.91)$ as an av. the two studied seasons respectively.

Therefore, it can be concluded that thrice spraying either of roselle or lemongrass as well as combined twice urea plus yeast at pre- bloom, full bloom and when berry at pea stage were the best tool to produce heavy weight of clusters and yield/vine.

\subsection{Cluster characteristics:}

Data in Table (2) showed the effects of tested treatments on cluster characteristics during the two studied seasons. It is evident that all treatments improved the cluster traits. Spraying GA3 or urea as well as roselle and lemongrass at prebloom significantly increased the cluster length, whereas, using them at full-bloom significantly decreased the berries number per cluster compared to untreated one (control). Hence, all spraying significantly decreased compactness coefficient of cluster and produced loose clusters. No significantly differences were detected due to use either GA3, urea roselle or lemongrass. The decrement of cluster compactness coefficient was attained (31.32, $27.99,27.00$ and $28.36 \%$ as av. of the two studied seasons) due to spray GA3, urea, roselle and lemongrass compared to unsprayed ones, (control) respectively. Also, these treatments significantly increased the berry weight compared to untreat one (control). The increment of berry weight was attained $36.32,35.12,36.62$ and 39.56 as an av. of the two studied seasons due to spray GA3, urea and yeast, roselle and lemongrass compared to untreated one respectively.
Using roselle or lemongrass for sizing had the highest berry weight and size with good cluster traits compared to control. No significant differences were observed between used GA3 or urea for cluster elongation and berry thinning, as well as used GA3 or yeast after berry set for sizing. In addition, roselle and lemongrass spraying three times gave the same positives effecting of GA3, urea and yeast on cluster attributes and berry weight.

\subsection{Chemical constituents:}

Data of various berry characteristics as affected by different studied treatments during 2018 and 2019 seasons are presented in Tables (3).

The data indicated that GA3 and urea plus active dry yeast spraying at pre-bloom, full bloom and pea stage as well as roselle and lemongrass three times significantly improved the Early Sweet Seedless grapes quality in terms of increasing total soluble solids and reducing sugars and decreasing total acidity compared to untreated ones. No significant differences were found due to use GA3 or urea plus yeast roselle or lemongrass. The increment percentage of total soluble solids was $(2.82,12.75,11.18$ and $12.75 \%$ as an av. of the two studied season) due to use GA3, urea twice plus yeast, roselle three times or lemongrass three times compared to unspray ones (control), respectively. Hence, it can be concluded that could be used either urea plus yeast, roselle or lemongrass instead of GA3 to overcome the adverse effects due to GA3 in grape production, i.e. delaying the berry ripening and reduction berry quality. 
Table (1): Effect of $\mathrm{GA}_{3}$, urea, yeast and plant extracts on berry set \%, shot berries, yield and cluster weight of Early sweet seedless grapes during 2018 and 2019 seasons.

\begin{tabular}{|c|c|c|c|c|c|c|c|c|c|c|c|c|}
\hline & \multicolumn{3}{|c|}{ Berry set (\%) } & \multicolumn{3}{|c|}{ Shot berries (\%) } & \multicolumn{3}{|c|}{ Yield/vine (kg) } & \multicolumn{3}{|c|}{ Cluster weight (g) } \\
\hline & 2018 & 2019 & Mean & 2018 & 2019 & Mean & 2018 & 2019 & Mean & 2018 & 2019 & Mean \\
\hline Control & 15.23 & 16.81 & 16.02 & 12.50 & 13.18 & 12.84 & 8.15 & 7.80 & 7.98 & 324.1 & 319.9 & 332.0 \\
\hline $\mathbf{G A}_{3}$ & 11.78 & 11.13 & 11.46 & 2.78 & 3.05 & 2.92 & 8.76 & 8.90 & 8.83 & 355.8 & 366.0 & 360.9 \\
\hline Urea + yeast & 11.44 & 12.36 & 11.90 & 2.90 & 2.65 & 2.78 & 8.84 & 9.10 & 8.97 & 360.0 & 368.6 & 364.3 \\
\hline Roselle & 11.32 & 11.83 & 11.58 & 2.60 & 2.15 & 2.38 & 8.75 & 9.18 & 8.97 & 361.0 & 384.6 & 372.8 \\
\hline Lemongrass & 11.95 & 11.31 & 11.63 & 2.32 & 2.00 & 2.16 & 9.10 & 9.25 & 9.17 & 374.3 & 381.9 & 378.1 \\
\hline L.S.D. & 1.63 & 1.34 & & 0.54 & 0.39 & & 0.53 & 0.48 & & 19.47 & 18.84 & \\
\hline
\end{tabular}

Table (2): Effect of $\mathrm{GA}_{3}$, urea, yeast and plant extracts on berries/cluster, cluster length, compactness coefficient and 25 berries weight of Early sweet seedless grapes during 2018 and 2019 seasons.

\begin{tabular}{|c|c|c|c|c|c|c|c|c|c|c|c|c|}
\hline & \multicolumn{3}{|c|}{ No. berries/cluster } & \multicolumn{3}{|c|}{ Cluster length } & \multicolumn{3}{|c|}{$\begin{array}{l}\text { Compactness } \\
\text { coefficient }\end{array}$} & \multicolumn{3}{|c|}{25 berries weight } \\
\hline & 2018 & 2019 & Mean & 2018 & 2019 & Mean & 2018 & 2019 & Mean & 2018 & 2019 & Mean \\
\hline Control & 129.3 & 132.7 & 131.0 & 16.10 & 16.22 & 16.16 & 8.03 & 8.18 & 8.11 & 58.23 & 57.88 & 58.06 \\
\hline $\mathbf{G A}_{3}$ & 105.2 & 102.2 & 103.7 & 18.73 & 18.52 & 18.94 & 5.61 & 5.53 & 5.57 & 76.75 & 81.55 & 79.15 \\
\hline $\begin{array}{l}\text { Urea } \\
\text { yeast }\end{array}$ & 106.0 & 108.3 & 107.2 & 18.27 & 18.36 & 18.31 & 5.80 & 5.88 & 5.84 & 74.10 & 82.80 & 78.45 \\
\hline Roselle & 107.0 & 105.6 & 106.3 & 17.92 & 17.98 & 17.95 & 5.95 & 5.87 & 5.92 & 76.75 & 81.88 & 79.32 \\
\hline Lemongrass & 104.3 & 101.5 & 102.9 & 17.77 & 17.80 & 17.79 & 5.91 & 5.71 & 5.81 & 80.85 & 81.30 & 81.03 \\
\hline L.S.D. & 9.64 & 8.75 & & 1.04 & 1.18 & & 0.36 & 0.43 & & 3.61 & 4.11 & \\
\hline
\end{tabular}


El-Salhy et al., : SVU-International Journal of Agricultural Sciences, 1 (2): 54-63, 2019

Table (3): Effect of GA3, urea, yeast and plant extracts on TSS, reducing sugars and titratable acidity of Early sweet seedless grapes during 2018 and 2019 seasons.

\begin{tabular}{lccccccccc}
\hline & & \multicolumn{3}{c}{ TSS \% } & \multicolumn{3}{c}{ Reducing sugars \% } & \multicolumn{2}{c}{ Titratable acidity \% } \\
\cline { 2 - 10 } & $\mathbf{2 0 1 8}$ & $\mathbf{2 0 1 9}$ & Mean & $\mathbf{2 0 1 8}$ & $\mathbf{2 0 1 9}$ & Mean & $\mathbf{2 0 1 8}$ & $\mathbf{2 0 1 9}$ & Mean \\
\cline { 3 - 10 } Control & 14.80 & 15.00 & 14.90 & 11.95 & 12.27 & 12.11 & 0.48 & 0.49 & 0.49 \\
GA3 & 15.33 & 15.40 & 15.32 & 12.73 & 12.95 & 12.84 & 0.50 & 0.48 & 0.49 \\
Urea & & & & & & & & & \\
yeast & 16.90 & 16.70 & 16.80 & 13.16 & 12.88 & 13.02 & 0.42 & 0.42 & 0.42 \\
Roselle & 16.72 & 16.60 & 16.66 & 13.15 & 13.16 & 13.11 & 0.42 & 0.43 & 0.43 \\
Lemongrass & 16.86 & 16.73 & 16.80 & 12.94 & 13.08 & 13.01 & 0.43 & 0.41 & 0.42 \\
L.S.D. & $\mathbf{0 . 6 1}$ & $\mathbf{0 . 5 7}$ & & $\mathbf{0 . 4 9}$ & $\mathbf{0 . 5 8}$ & & $\mathbf{0 . 0 2}$ & $\mathbf{0 . 0 2}$ & \\
\hline
\end{tabular}

\section{Discussion}

GA3 spraying at full bloom decreased berry set since its role in flower dropping, causing a reduction of berries number of cluster. GA3 stimulate cell elongation process, enhancing the water absorption and stimulating the biosynthesis of proteins which will lead to increase the cluster length, as well as, berry size and weight (Roper and Williams, 1989; Perez et al., 2000, Dokoozlian and Peacock, 2001; El-Salhy et al., 2009 and Abu-Zahra, 2010).

Our results showed that GA3 spraying decreased berry set about 28.46\%, shot berries about $77.26 \%$ and cluster compactness coefficient, $31.30 \%$. On other hand such spraying increased the cluster weight about, $8.70 \%$ and berry weight about $36.32 \%$.

The results are on line with those obtained by the investigators, Orth (1990), Lu et al. (1995), El-Halaby et al., (2015) and Radwan et al. (2019).
Low buiret urea differed significantly in term of fruit set and fruit thinning percentage. The reasons may be the interference with fertilization of the ovary of phytotoxicity in the peduncle region Guirguis et al., (1996) and Ahmed et al., (2004). There was a remarkable improving on berry quality expressed on increasing the berry weight, total soluble solids, reducing sugars and anthocyanin contents as berry thinning.

The improving effect of yeast application was attributed to auxins, hormones, vitamins, chelating agents and enzyme produced which have stimulatory effects on cell division and enlargement, nutrient uptake, protein synthesis and improves net photosynthesis, Moor, (1979) and Idso et al. (1995). These effects induce advancing of the berry ripening. It known that the earliest productions are the most important target for export and marketing. The results of urea on improving yield and berry quality of grapevines was supported by many authors such as Ahmed et al. (2004), El-Salhy et al. (2009), Fawzi et al. (2014), El- Halaby et al. (2015) and Radwan et al. (2019). 
Obtained results indicated that spraying urea twice followed yeast have a decreasing in berry set about $25.72 \%$, shot berries about $78.35 \%$ and cluster compactness coefficient about $27.99 \%$, whereas, using the same treatment increased the cluster weight about $4.27 \%$, berry weight about 35.13 and TSS about $12.75 \%$. The results are in harmony with those of Omran and Abdel-Latif (2003), El-Salhy et al. (2011), Fawzi et al. (2014) and El-Halaby et al. (2015).

The higher own content of plant extracts from different antioxidant as well as nutrients surely reflected on enhancing cell division, building organic foods and the tolerance of plants to biotic and abiotic stresses could explain the positive effects on growth and fruiting of fruit trees, Paik and Chung (1997); Pons (2003) and Okigobo and Emoghene (2003).

Lemongrass oil was used as a photosynthetic inhibitor alone or in combination with the other thinners to induce flower and fruit abscission (Byers et al., 1990). These effects surely reflected on enhancing growth, nutritional status and fruiting of vines.

Also, our data decleared that using roselle or lemongrass induce a decreasing of berry set percentage about (27.72 \& 27.40\%), shoot berries about $(81.46 \& 83.18 \%)$ and cluster compactness coefficient about $(27.00$ \& $28.36 \%$ ), respectively. On other hand, had an increasing of cluster weight about (12.29 \& $13.89 \%)$, berry weight (36.62 \& $39.56 \%)$ and TSS about (11.78 \& 12.75\%), respectively. These results were reported by Vargas et al. (2008), Gadel-Kareem and Abdel-Rahman (2013), Abd-Allah et al. (2013), Ahmed et al. (2014), Gouda-Fatma El-Zahraa (2016) and El-Salhy et al. (2017).

\section{Conclusion}

On the light of the previous results, it could be .recommended that spraying of GA3 seven times, once at prebloom, thrice at fullbloom and thrice $(5,10 \& 30 \mathrm{ppm})$ when the berry of pea stage. In addition, can be used either $1.5 \%$ low biuret urea at prebloom and full bloom, Plus $0.4 \%$ active dry yeast when the berry at pea stage roselle or lemongrass three times. Using urea and yeast as well as roselle more effective to overcome the adverse effective of using GA3 at high concentration i.e. delay the berry ripening. These treatments very necessary to produce heavy and less compact cluster and hasten the ripening as well as improving the taste of Early Sweet Seedless berries. These advantages will eventually enable growers to obtain highly marketable surrounding and overseas markets.

\section{Acknowledgements}

Financial support provided by Research Management Fund of South Valley University, Egypt is gratefully acknowledged.

\section{Conflict of interest}

The authors hereby declare that no competing and conflict of interests exist.

\section{References}

Abd-Allah, A.S.E., Abdel-Razek, E., Abdalla M.A. and Saleh M.M.S. (2013) 'Effect of spraying lemongrass extract at full bloom on yield and fruit quality of Flame Seedless grape'. J. of Applied Sci. Research, 9 (2): 1244-1248.

Abdel-Aal, A.M. and Aly M.M. (2013) 'The synergistic effects of using turmeric with some antioxidants on growth, vine nutritional status and productivity of Ruby Seedless grapevines'. Hort. Science J. of Suez Canal Univ., Vol. (1): 305-308.

Abdel-Hady, A.M. (1995) 'Response of 
Roomy Red grapevines to foliar sprays of urea and boron', Ph.D. thesis, Fac. of Agric., Minia Univ., Egypt.

Abu-Zahra, T.R. (2010) 'Berry size of Thompson Seedless as influenced by the application of gibberellic acid and cane girdling', Pak. J. Bot., 42 (3): $1755-1760$

Ahmed, W., Junaid, M. Amin S. and Nafees, M. (2004) 'Low biuret urea application at different phenophases of bunch to improve productivity of perlette grapes Inter', J. of Agri. \& Bio. 6 (2): 418-419.

A.O.A.C. (1985) 'Official methods of Analysis, A.O.A.C., Benjamin Franklin Station', Washington D.C., U.S.A. pp. 440-512.

Byers, R.E. and Lyons, C.G. (1985) 'Peach flower thinning and possible site of action of desiccating chemicals', $J$. American Soc. Hort. Sci., 110: 662667.

Byers, R.E., Barden, J.A., Polomski, R.F., Young, R.W. and Carbough D.H. (1990) 'Apple thinning by photosynthetic inhibition', J. Amer. Soc. hort. Sci., 115: 14-19.

Colapietra, M. L., Tarricone. and Tagliente, G. (1995) 'Effects of gibberellic acid and cluster thinning on the qualitative characteristics of table grape Centennial Seedless', Rivista di frutticolturaedi ortofloricoltura 57 (5): 65-70. (Hort. Abst., 65: 6923).

Dimitri, C. and Oberholtzer L. (2006) 'Eu and U.S. organic markets face strong demand under different policies', Amber waves. Economic Research Service USDA, 4: 12-19.

Dokoozlian, N.K. and Peacock W.L. (2001) 'Gibberellic acid applied at bloom reduces fruit set and improves size of "Crimson Seedless" table grapes', Hort. Sci., Vol. 36, No. 4, pp. 706-709.

El-Halaby, E.H.S., El-Salhy, A.M., AlWasfy, M.M. and Ibrahim R.A. (2015) 'Effect of $\mathrm{GA}_{3}$, Urea and Yeast Spraying on Fruiting of Flame Seedless Grapevines under Sandy Soil Conditions', Assiut J. Agric. Sci., 46 (2): 95-106.

El-Moursy, F.M., Ahmed, F.F. and AbdelAziz, F.A. (1993) 'Benefits of spraying urea and boron for Red roomy grapevines', Minia First Conf. for Hort. Crop.

El-Salhy, A.M., Ahmed-Amin, K.I., A.A.B. Masoud A.A.B. and A.A. Abozeed A.A. (2011) 'Response of Ruby Seedless and Red Roomy grapevines to application of some bio fertilizers', Assiut J. of Agric. Sci., 41 (5): 125 142.

El-Salhy, A.M., Ahmed-Amin, K.I., Masoud, A.A.B. and A.A. Abozeed A.A. (2009) 'Effect of berry thinning, CPPU spraying and pinching on cluster and berry quality of two grapevine cultivars', Assiut J. of Agric. Sci., 40 (4): 92-107.

El-Salhy, A.M., Ibrahim, R.A., M.A. Mgawe ,M.A. and Abd El-Hafiz, G.N. (2017) 'Effect of some plant extracts spraying on growth and fruiting of Flame seedless grapevines', Assiut J. of Agric. Sci., 48 (3): 188-197.

Fawzi, M.I.f., Laila ,F., Haggag, M.F., Shahin, M.A., Merwad. and Genaidy E.A. (2014) 'Influence of spraying urea, boron and active dry yeast on growth, yield, leaf chemical composition and fruit quality of Superior grapevines growth in sandy 
soil conditions', Middle East J. of Applied Sci. 4 (3): 740-747.

Gadel-Kareem, M.R. and Abdel-Rahman, M.A (2013) 'Response of Ruby Seedless grapevines to foliar application of seaweed extract, salicylic acid and roselle extract', HortScience J. of Suez Canal Univ., pp. 299-303.

Gomez, K.A. and Gomez, A.A. (1984) 'Statistical Procedures for Agricultural Research $2^{\text {nd }}$ Ed', Wily, New York.

Gouda-Fatma El-Zahraa, M. (2016). Effect of $\mathrm{GA}_{3}$ and lemongrass oil spraying on fruiting of Ruby Seedless grapevines. Assiut J Agric. Sci., 47 (6-1): 173-180

Guirguis, N.S., Gumana, A.H., Stino, R.G. and Merhreki ,A.M. (1996) 'Effect of carbonate, urea and cyanamide on thinning and apical blooms under arid conditions in Egypt', Hort. Abst.66:92.

Hassan, A.S.A. (2002) 'Effect of some $\mathrm{GA}_{3}$, yeast, nitrogen, and potassium foliar spray treatments on yield, fruit quality and leaf characteristics of Thompson Seedless', Zagazig J. Agric. Res., Vol. 29 (1): 73 - 97.

Idso, S.B., Idso, K.E., Garcia, R.L., Kimbal, B.A. 1. and Hoober,J.K. (1995) 'Effect of atmospheric $\mathrm{Co} 2$ enrichment and foliar methanol application on net photosynthesis of sour orange trees (Citrus aurantium, Rutaceae) leaves',Amer.J. of Botany, 82 (1): 2630.

Lu, J.O., Lamikanra, O. and Leong, S. (1995) 'Effect of gibberellic acid on muscan dine grape production. Proc. Folia', State Hort. Soc. 108: 360-361.

M.A.L.R. (2016) 'Ministry of Agriculture and Land Reclamation Publishes
Economic Affairs',

Moor, T.C. (1979) 'Biochemistry and physiology of plant hormones', Pub. By Springer-Verlag New York, USA.

Okigobo, B. N. and Emoghene, A.O. (2003) 'Effect of leaf extract of three plant species on Mycospharella fifiensis Morelet, the casual organism of black sigatoka disease of banana (Musa acuminate) Nigeria journal of plant protection', 20: 101-110.

Omran, Y.A.M. and Abdel-Latif, H.A. (2003) 'Examining of some genetically improved yeast strains on vine vigor, yield components and fruit quality of Red Roomy grapevines', Assiut J. Agric. Sci., 34 (1): 33- 42.

Orth, C.H.F. (1990) 'Effect of spraying or dipping Muscat Seedless with gibberellic acid at different flowering stage on berry set and berry size', Deciduous Fruit Grower 40 (11): 428432. (Hort. Abst., 62: 3826).

Paik, S. and Chung, I. (1997) 'Effect of medicinal plant extracts on apple storage disease', Korean J. of plants pathology, 13:57-62.

Perez, F.J., Vionic ,C. and Retamales, J. (2000) 'Bioactive gibberellins in seeded and Seedless grapes; identification and changes in content during berry development', Am. J. Enol Vitis, 51: 315-318.

Poni, S. (2003) 'Summer pruning in vineyards. Physiology and cultural aspects',Informatore Agrario, 59 (26): 37-49.

Radwan, E.M.A., Khodair, O.A. and Silem, A.A.E.M. (2019) 'Effect of some compounds spraying on fruiting of Superior Seedless grapevines under 
El-Salhy et al., : SVU-International Journal of Agricultural Sciences, 1 (2): 54-63, 2019

Assiut conditions', J. Plant

Production, Mansoura Univ., 10 (1): 59-64.

Raffauf, R.P. (1970) ' Handbook of Alkaloids and Alkaloid containing plants', Willy \& Sons, pp.10-20.

Roper, T.R. and Williams, L.E. (1989) 'Net Co2 assimilation and carbohydrate partitioning of grapevine leaves response to trunk girdling and gibberellic acid application', Plant Physiology, 89: 1136-1140.

Shab,G.,Shri,R., $\quad$ Panchal,V.,Sharma,N., Singh,B. and Mann ,A.S. (2011) 'Scientific basis for the therapeutic use of cynobopogen citratus stapf (lemongrass)',J. Adv. Pharm. Tech. Res., 2: 3-8.

Snedecor, G.W. and Cochran, W.G. (1990) ' Statistical Methods 7th Ed', The Iowa State Univ., Press.

Srimal, R.C. (1997) 'Turmeric a brief review of medicinal properties of leaf extract of some plants', Indian Phytopath. 50 (3): 408-5011.

Srivastava, A.K. and Lal, B. (1997) 'Studies on bio fungicidal properties of leaf extract of some plants',Indian Phytopath. 50 (3): 408-4011.

Uwalkiem, M.Kh. (2014) ' The synergistic effect of spraying some plant extracts with some macro and micronutrients of Thompson Seedless grapevines', Inter. J. of Plant and Soil Sci., 3 (10): 12901301.

Vargas, I., Corrales ,B. and Martinez ,M. (2008) 'Compounds derived from garlic as bud induction agent in organic farming of table grape',Chilean $J$. Agric. Res., 68: 94-101.
Williams, L.E. and Ayars, J.E. (2005) 'Water use of Thompson Seedless grapevines as affected by the application of gibberellic acid $\left(\mathrm{GA}_{3}\right)$ and trunk girdling-practices to increase berry size', Agric. and Forest Meteorology, 129: 85-94.

Winkler,A.J., Cook,A.J., Kliwer,W.M. and Lider,L.A. (1974) 'General viticulture', Published by University of California Press, Barkley. 